\title{
Analisis Leverage Dalam Mengukur Risiko Studi Kasus Pada PT. Pabrik Kertas Tjiwi Kimia Tbk
}

\author{
Andi Amri \\ Universitas Pancasila, Jakarta \\ Email: 5119220003@univpancasila.ac.id
}

\begin{abstract}
The purpose of this study is to look at the risk of PT. Tjiwi Kimia Tbk Paper Plant in terms of business risks, financial risks, and total risk caused by looking at specific problems within the company to obtain various measures that are useful for measuring risk levels. Form of research that uses observation by using descriptive analysis method to describe course of an ongoing research or looking for problems that occur in the company where the author wakes up research. Result of research: 1). Operating Leverage (DOL) for the last six years has not been good, because the resulting DOL tends to increase this meaning the company has not been able to reduce its business risk. 2) The resulting Financial Leverage (DFL) contains a downward trend which can be seen from the decrease in EPS generated so that the company has not been able to reduce its financial risk. 3) Total Leverage (DTL) generated can still change, with DTL result every year tends to increase and decrease (inconsistent) seen from variation of EPS produced every time following sales up and down. PT. Tjiwi Kimia Tbk Paper Plant can reduce the total risk if it can drop DOL and increase DFL.
\end{abstract}

Keywords Financial, operating, total leverage

\section{Pendahuluan}

Dalam mencapai visi dan misi, perusahaan dihadapkan dengan banyaknya ketidakpastian dan cepatnya perubahan lingkungan usaha baik internal maupun eksternal. Ketidakpastian ini sering kali disebut dengan risiko bisnis. Secara umum, perusahaan tentunya memiliki kesadaran akan adanya risiko dan kesadaran pengelolaan atas risiko tersebut. Pengertian risiko sendiri adalah kekhawatiran adanya suatu peristiwa di masa depan yang kemungkinan akan berdampak negatif atau tidak mengguntungkan terhadap pencapaian sasaran yang sudah ditentukan perusahaan (Brigham \& Houston, 2010).

Sebelum peristiwa tersebut terjadi, manajemen perusahaan akan melakukan dan menganalisis langkah-langkah antisipasi, baik untuk mengurangi kemungkinan terjadinya, maupun untuk memitigasi dampaknya, salah satu caranya dengan melihat dan mengukur seberapa besar risiko yang terjadi dalam perusahaan tersebut. Syamsuddin (2009) menyatakan sebuah perusahaan, risiko yang dihadapi oleh perusahaan yaitu risiko operasi, risiko keuangan dan risiko total. Sebelum peristiwa tersebut terjadi, manajemen perusahaan akan melakukan dan menganalisis langkah-langkah antisipasi, baik untuk mengurangi kemungkinan terjadinya, maupun untuk memitigasi dampaknya, salah satu caranya dengan melihat dan mengukur seberapa besar risiko yang terjadi dalam perusahaan tersebut. Syamsuddin (2009) menyatakan sebuah perusahaan, risiko yang dihadapi oleh perusahaan yaitu risiko operasi, risiko keuangan dan risiko total.

Risiko operasi atau operating risk merupakan keadaan dimana perusahaan tidak mampu menutup operating cost. Meningkatnya fixed operating cost maka penjualan pun harus ditingkatkan agar biasa menutup semua operating cost. Risiko keuangan atau financial risk merupakan keadaan dimana perusahaan tidak mampu menutup biaya-biaya finansialnya. 
Sedangkan total risiko mencerminkan total risiko yang dikaitkan dengan kemampuan perusahaan untuk menutup operating cost maupun financial cost. Jadi, salah satu alat untuk mengukur resiko yang paling tepat adalah analisis leverage. Analisis leverage dapat digunakan untuk meningkatkan hasil pengembalian pemegang saham, tetapi dengan risiko akan meningkatkan kerugian pada masa-masa suram (Keown, 2010).

Ada 3 jenis leverage yaitu leverage operasi, leverage keuangan dan leverage kombinasi. Leverage operasi menggambarkan struktur biaya perusahaan yang dikaitkan dengan keputusan manajemen dalam menentukan kombinasi asset perusahaan. Penggunaan aktiva tetap yang semakin relatif tinggi akan menimbulkan proporsi biaya yang relatif tinggi terhadap biaya variabel. Proporsi biaya yang tinggi menunjukkan leverage operasi perusahaan yang tinggi, yang berarti semakin tinggi tingkat sensitivitas kinerja (kembalian) perusahaan terhadap perubahan kembalian pasar. Leverage keuangan menggambarkan tingkat sumber dana hutang dalam struktur modal perusahaan. Penggunaan hutang yang relatif tinggi menimbulkan biaya tetap (beban tetap) dan dengan demikian meningkatkan risiko. Sedangkan leverage kombinasi menggambarkan penggunaan biaya operasional tetap dan pendanaan tetap oleh perusahaan (Husnan, 2008).

Menurut Keown (2010) menyatakan operating leverage digunakan untuk mengukur tingkat kepekaan penjualan terhadap EBIT. Operating leverage ini dimungkinkan karena terdapatnya biaya tetap dalam struktur biaya perusahaan. Meskipun operating leverage dapat meningkatkan EBIT, pada sisi lain, yaitu tingkat penjualan yang rendah bahkan akan menurunkan EBIT. Analisa financial leverage mengukur tingkat kepekaan perubahan EPS karena perubahan dalam EBIT. Financial leverage timbul jika perusahaan mempunyai hutang jangka panjang dengan bunga tetap untuk membiayai investasinya. Degree of financial leverage menunjukkan perubahan dalam EPS karena perubahan dalam EBIT. Dengan demikian dapat naik atau turun tergantung perubahan EBIT. Sedangkan Combined leverage mengukur tingkat penjualan terhadap perubahan EPS. Degree of combined leverage mengukur tingkat perubahan persentase dalam EPS perusahaan yang dihasilkan dari perubahan output (penjualan).

Maksud dan tujuan dari analisis leverage terhadap Perusahaan Manufaktur adalah untuk melihat risiko perusahaan dalam mengelola risiko bisnisnya, mengelola risiko keuangan, dan melihat risiko total yang ditimbulkan dengan melihat masalah khusus dalam perusahaan manufaktur adalah persediaan, biaya pabrikasi (manufacturing costs), biaya produksi dan beban pokok produksi guna mendapatkan berbagai indikasi yang berguna untuk mengukur tingkat risiko.

Perusahaan manufaktur dapat membantu masyarakat dalam memenuhi kebutuhan hidupnya sesuai dengan waktu dan kondisi pada saat itu, tentunya dibutuhkan kepercayaan masyarakat terhadap perusahaan yang bergerak dalam bidang ini agar produk yang dihasilkan terjual dan mendapatkan laba sesuai target yang diinginka perusahaan tersebut. Dengan banyaknya perusahaan manufaktur yang ada pada saat ini, membuat para peneliti, pengguna dan pengkonsumsi produk perusahaan manufaktur dapat memilih sesuai dangan kebutuhannya dengan benar-benar melihat dan mengukur risiko tersebut sebelum digunakan melalui laporan keuangan dalam rentang beberapa tahun. Masyarakat tidak bisa percaya begitu saja kepada perusahaan manufaktur yang kurang memberikan informasi seperti salah satunya risiko usaha dan faktor-faktor yang mendukung risiko tersebut.

Berdasarkan situs resmi www.idx.co.id (2020), PT. Pabrik Kertas Tjiwi Kimia Tbk didirikan 
pada tanggal 2 Oktober 1972, berkedudukan di Desa Kramat Tumenggung, Kecamatan Tarik, Sidoarjo, Jawa Timur. Kegiatan utama perusahaan ini adalah memproduksi berbagai jenis kertas tulis dan cetak, baik coated maupun uncoated. Selain itu, perusahaan juga memproduksi beragam jenis hasil-hasil produksi kertas (stationery) dan produk perlengkapan kantor seperti buku tulis, memo, loose leaf, spiral, amplop, kertas komputer, kertas kado, shopping bag, dan produk fancy yang diminati pasar internasional. Sesuai dengan permintaan pasar, perusahaan ini memproduksi kertas yang memiliki nilai tambah termasuk kertas tanpa karbon dan kertas cast coated dan board.

Keadaan laporan keuangan PT. Pabrik Kertas Tjiwi Kimia Tbk pada enam tahun terakhir dilihat dari pendapatan dan EBIT yang mengalami naik turun cukup berarti, naik atau turun ini diikuti dengan naik atau turun EPS, begitu pula dari biaya tetap, biaya variabel, dan hutang perusahaan juga mengalami kenaikkan dan juga penurunan. Tetapi hal ini belum mencerminkan risiko PT. Pabrik Kertas Tjiwi Kimia Tbk dalam memperoleh laba atau rentabilitas. Tujuan penelitian ini adalah mengetahui tingkat risiko operasi perusahaan berdasarkan DOL (Degree of Operation leverage) dengan menggunakan analisis Leverage operasi, tingkat risiko keuangan perusahaan berdasarkan DFL (Degree of financial leverage) dengan menggunakan analisis Leverage keuangan, dan tingkat risiko total perusahaan berdasarkan DCL (Degree of combined leverage) dengan menggunakan analisis Leverage operasi keuangan. Penelitian ini diharapkan bermanfaat dalam menambah ilmu pengetahuan khususnya manajemen keuangan, secara khusus diharapkan dapat memberikan masukan dan sumbangan pemikiran dalam pengambilan keputusan bagi perusahaan. Dengan adanya fenomena di atas, Analisis Leverage dapat diukur untuk melihat risiko perusahaan dalam menggunakan pendapatan yang ada untuk usaha-usaha yang menghasilkan EPS yang cukup bagi pemegang saham dan menilai laba yang diperoleh untuk suatu periode tertentu sehingga dapat meyakinkan masyarakat. Oleh karena itu, penelitian ini berjudul "Analisis Leverage Dalam Mengukur Risiko Studi Kasus Pada PT. Pabrik Kertas Tjiwi Kimia Tbk”.

\section{Tinjauan Literatur}

\subsection{Risiko}

Definisi risiko menurut Charette (2006), Risiko ialah sesuatu yang berhubungan dengan kejadiaan dimasa mendatang yang melibatkan perubahan seperti perubahan pikiran, pendapat, aksi, atau tempat dan juga melibatkan pilihan dan ketidakpastian bahwa pilihan itu akan dilakukan. Sedangkan Tandelilin (2001), menjelaskan Risiko sebagai kemungkinan perbedaan antara return actual yang diterima dengan return yang diharapkan. Semakin besar kemungkinan perbedaan maka semakin besar risiko investasi tersebut. Risiko ini biasanya berhubungan dengan leverage dan risiko dimana kewajiban dan liabilitas tidak bisa dipertemukan dengan aset lancar. Sementara Idroes (2011), menejlaskan risiko memiliki dua makna, yaitu : (1) Risiko merupakan bahaya, maksudnya risiko adalah ancaman atau kemungkinan suatu tindakan atau kejadian yang menimbulkan dampak yang berlawanan dengan tujuan yang ingin dicapai dan (2) Risiko juga merupakan peluang, maksudnya risiko adalah sisi yang berlawanan dari peluang untuk mencapai tujuan.

Jadi risiko merupakan ketidakpastian kemampuan perusahaan membayarkan kewajiban tetap yang akan menimbulkan kehilangan atau mengalami kerugian/kerusakan yang tidak diharapkan. Risiko itu hamper pasti terdapat pada segala kegiatan yang dilakukan oleh manusia. Ketika risiko itu datang, tidak dapat diprediksi dengan benar. 


\subsection{Faktor-faktor Risiko Perusahaan Manufaktur}

Menurut Brigham \& Houston (2011), Risiko bisnis bergantung pada sejumlah faktor, yaitu:

a. Variabilitas permintaan,

Makin stabil permintaan akan produk suatu perusahaan, maka hal-hal lain yang dianggap konstan, akan makin rendah risiko usahanya.

b. Variabilitas harga jual,

perusahaan yang produknya dijual ke dalam pasar yang sangat labil akan menghadapi risiko usaha yang lebih besar dibandingkan perusahaan serupa yang harga keluarannya lebih stabil.

c. Variabilitas biaya masukan,

Perusahaan yang biaya masuknya sangat tidak pasti akan menghadapi tingkat risiko usaha yang tinggi.

d. Kemampuan untuk menyesuaikan harga keluaran terhadap perubahan dalam biaya masukan,

Beberapa perusahaan memiliki kemampuan yang lebih baik dibandingkan perusahaan lain untuk menaikkan harga keluarannya ketika biaya masukan meningkat. Makin besar kemampuan untuk menyesuaikan harga keluaran untuk mencerminkan kondisi biaya, makin rendah tingkat risiko usahanya.

e. Kemampuan untuk mengembangkan produk baru dengan cara yang tepat waktu dan efektif biaya,

Perusahaan di dalam industri berteknologi tinggi seperti obat-obatan dan computer bergantung pada aliran konstan produk-produk baru. Makin cepat produknya menjadi usang, makin besar risiko usaha suatu perusahaan.

f. Pemaparan risiko luar negeri,

Perusahaan yang menghasilkan sebagian besar labanya di luar negeri akan menjadi subjek dari penurunan laba akibat fluktuasi nilai tukar. Begitu pula jika perusahaan beroperasi disuatu wilayah yang kondisi politiknya tidak stabil perusahaan tersebut bisa jadi merupakan subjek dari risiko politik.

g. Sejauh mana tingkat biaya-biaya yang merupakan biaya tetap.

Jika sebagian besar biaya perusahaan merupakan biaya tetap, maka biaya tidak akan turun meskipun permintaan merosot, maka perusahaan tersebut menghadapi tingkat risiko usaha yang relatif tinggi.

\subsection{Jenis-jenis Risiko Perusahaan Manufaktur}

Secara umum, risiko ada 2, yaitu risiko bisnis dan risiko keuangan. Risiko bisnis adalah tingkat risiko dari aktiva perusahaan jika tidak menggunakan utang, dan Risiko keuangan adalah risiko tambahan bagi pemegang saham biasa akibat keputusan penggunaan utang (Brigham dan Houston, 2001). Risiko yang melekat pada perusahaan manufaktur termasuk risiko bisnis, dimana risiko ini tidak terlepas dari karakteristik utama kegiatan perusahaan yaitu kegiatan memperoleh sumberdaya, mengolah sumberdaya menjadi barang jadi serta menyimpan dan mendistribusikan barang jadi.

Menurut Surat Edaran Ketua Badan Pengawas Pasar Modal (2002) risiko-risiko yang melekat pada perusahaan manufaktur sebagai berikut: (1) Risiko sulitnya memperoleh bahan baku yang disebabkan oleh kelangkaan bahan baku dan ketergantungan yang tinggi terhadap impor atau pemasok tertentu. (2) Risiko berfluktuasinya nilai tukar rupiah. Berflkutuasinya nilai 
tukar dapat dilihat dari dua sisi, yaitu: Depresiasi rupiah berakibat buruk bagi perusahaan yang penjualannya mengandalkan pasar lokal dan tergantung pada bahan baku impor. Meningkatnya harga jual produk jadi yang melebihi daya beli masyarakat akan berakibat menurunya penjualan perusahaan. Pada sisi lain, depresiasi rupiah mengguntungkan perusahaan yang mendandalkan pasar ekspor dan tergantung pada bahan baku yang pengadaanya dalam nilai tukar rupiah. Apresiasi rupiah pada sisi sebaliknya, berpengaruh negatif terhadap perusahaan yang mengandalkan penjualannya pada pasar ekspor. (3) Risiko kapasitas produksi tidak terpakai (idle capacity) yang terjadi karena kurangnya daya serap pasar terhadap produk, kompetisi, dan perubahaan teknologi, dan lain-lain. (4) Risiko terjadinya pemogokan atau kerusuhan (riot) yang antara lain dapat terjadi karena ketidakpuasan karyawan terhadap kompensasi yang diterima, kondisi perekonomian atau kondisi politik yang tidak stabil. (5) Risiko kekakuan investasi yaitu karena adanya restriksi/pembatasan pemerintah terhadap investasi pada bidang tertentu. (6) Putusnya hak patent (patent right) atas formula produksi bagi perusahaan yang produknya terkait erat pada hak paten atas formula tertentu akan sangat mempengaruhi pendapatannya. (7) Risiko leverage, yaitu risiko-risiko yang terkait pada kewajiban perusahaan karena pendanaan yang berasal dari luar perusahaan (external financing). (8) Risiko pemasaran meliputi, antara lain tidak terjualnya barang jadi, kerusakan dan kehilangan pada jalur distribusi dan pemasaran, habisnya daur hidup produk. (9) Risiko penelitian dan pengembangn produk meliputi, antara lain biaya penelitian dan pengembangan yang gagal menghasilkan produk baru. (10) Risiko dampak usaha terhadap lingkungan yang tercermin dari peringkat analisis mengenai dampak lingkungan (amdal) yang diberikan oleh Bapedal dan unjuk rasa ketidakpuasan penduduk di lingkungan setempat. (11) Risiko tidak tertagihnya piutang (accounts receivable risk), yaitu resiko yang muncul karena rendahnya kolektabilitas piutang. Risiko ini terkait langsung pada industri manufaktur, karena sistem penjualan pada industri manufaktur umumnya tidak dilakukan secara kas.

\subsection{Laporan Keuangan}

Laporan keuangan adalah beberapa lembar kertas yang bertuliskan angka-angka, tetapi sangat penting juga untuk memikirkan aktiva ril dibalik angka-angka tersebut. Laporan keuangan merupakan hasil akhir dari proses akuntansi yang meliputi dua laporan utama yakni neraca dan laporan rugi laba (Subramanyam \& Wild, 2011). Brigham (2011) menjelaskan laporan keuangan yang diterbitkan perusahaan kepada pemegang saham, laporan tahunan (annual report) adalah laporan yang paling penting. Ada dua jenis informasi yang diberikan dalam laporan ini. Pertama, adalah bagian verbal, yang sering kali disajikan sebagai surat dari presiden direktur yang menguraikan hasil operasi perusahaan selama tahun lalu dan membahas perkembangan baru yang akan mempengaruhi operasi perusahaan di masa depan. Kedua, laporan tahunan yang menyajikan empat laporan keuangan dasar neraca, laporan labarugi, laporan laba ditahan, dan laporan arus kas. Laporan -laporan tersebut menyajikan angkaangka akuntansi dari operasi dan posisi keuangan perusahaan.

\subsection{Pengertian Analisis Leverage}

Leverage adalah penggunaan dana untuk menanggung biaya tetap sehingga meningkatkan profitabilitas. Leverage dipergunakan untuk menggambarkan kemampuan perusahaan untuk menggunakan aktiva atau dana yang mempunyai beban tetap (fixed cost asset of funds) untuk memperbesar tingkat penghasilan (return) bagi pemilik perusahaan (Husnan, 2008). 


\subsection{Jenis-jenis Leverage}

Ada 3 jenis Leverage yang digunakan untuk mengukur risiko sebuah perusahaan, yaitu:

a. Leverage operasi (peluang untuk meningkatkan keuntungan sebelum bunga dan pajak melalui peningkatan penjualan).

Rumus

$$
\mathrm{DOL}=\frac{\% \text { Perubahaan EBIT }}{\% \text { Perubahaan Penjualan }}
$$

b. Leverage keuangan (peluang meningkatkan keuntungan sebelum bunga dan pajak melalui penggunaan dana pinjaman).

Rumus

$$
\mathrm{DFL}=\frac{\% \text { Perubahaan EPS }}{\% \text { Perubahaan EBIT }}
$$

c. Total leverage (total peluang untuk meningkatkan keuntungan melalui peningkatan operasi dan penggunaan dana dari luar berupa pinjaman atau utang) (Husnan, 2008, 614).

Rumus

$$
\mathrm{DTL}=\frac{\% \text { Perubahan EPS }}{\% \text { Perubahan Penjualan }}
$$

\subsection{Perusahaan Manufaktur}

Perusahaan Manufaktur merupakan suatu perusahaan yang mengolah bahan baku menjadi barang jadi untuk dijual dan dikonsumsi manusia, dengan kegiatan utama memperoleh atau menyimpan bahan baku, mengolah bahan baku, dan menyimpan serta memasarkan barang jadi (Dina, 2007).

\section{Metode Penelitian}

Jenis penelitian ini adalah penelitian deskriptif, merupakan metode yang digunakan untuk menggambarkan atau menganalisis suatu hasil penelitian tetapi tidak digunakan untuk membuat kesimpulan yang lebih luas (Sugiyono, 2010, 29). Metode deskriptif digunakan untuk menggambarkan rumusan masalah. Data yang dibutuhkan adalah data yang sesuai dengan masalah-masalah yang ada dan sesuai dengan tujuan penelitian, sehingga data tersebut akan dikumpulkan, dianalisis dan diproses lebih lanjut sesuai dengan teori-teori yang telah dipelajari, jadi dari data tersebut akan ditarik kesimpulan.

Penelitian ini dilakukan dengan menggunakan data sekunder. Data sekunder merupakan sumber data penelitian yang diperoleh peneliti secara tidak langsung melalui media perentara (diperoleh dan dicatat oleh pihak lain), berupa soft copy laporan keuangan yang diperoleh melalui website http://idx.co.id.

Penelitian ini dilakukan pada PT. Pabrik Kertas Tjiwi Kimia Tbk. Penulis melakukan penelitian dengan menggunakan data sekunder dan jenis data time series dari tahun 2009 sampai 2014 melalui website http://idx.co.id. Waktu penelitian dilakukan pada tanggal 13 
April sampai 27 April 2017.

Tahapan dalam penyelesaian penelitian ini diantaranya, yaitu: (1) Mendefinisikan masalah, Sebelum membuat suatu penelitian, maka terlebih dahulu merumuskan masalah apa yang akan dibahas dan menjelaskannya secara ringkas dan jelas. (2) Mengadakan studi kepustakaan, Studi kepustakaan memiliki kegunaan sebagai bahan atau teori yang digunakan dalam pengolahan data penelitian yang akan di analisis atau diinterpretasikan. (3) Mengumpulkan data, Untuk memperoleh hasil penelitian, maka sebelumnya penulis harus mengumpulkan data-data yang sesuai dengan masalah yang akan dibahas, yaitu berupa akunakun yang terdapat di Laporan Laba Rugi dan data ini berbentuk data dokumentasi yang diperoleh dari perusahaan yang go public dan terdaftar di Bursa Efek Indonesia (BEI). (4) Menyusun, menganalisis, dan memberikan interpretasi, dan membuat kesimpulan, Setelah data diperoleh data berupa akun-akun yang berada di Laba Rugi (pendapatan, EBIT, dan EPS), maka penyusunan penelitian pun dilakukan sesuai aturan dan hasil pengolahan data akan dianalisis dan dijelaskan berdasarkan teori-teori yang ada. (5) Membuat kesimpulan. Hasil dari penelitian tersebut akan diberi kesimpulan yang bertujuan setelah hasil analisis didapat, penulis menginterpretasikan hasil analisis dengan tujuan untuk memberikan jawaban secara tegas atas rumusan masalah.

Berdasarkan jenis penelitian yang sudah dijelaskan sebelumnya, maka objek dari penelitian ini adalah laporan keuangan PT. Pabrik Kertas Tjiwi Kimia Tbk. dari tahun 2009 sampai 2014 yang terdiri dari laporan laba rugi.

Untuk teknik analisis, penulis menggunakan metode analisis deskriptif yang menjelaskan, memaparkan, dan menggambarkan data-data yang diperoleh selama melakukan penelitian pada PT. Pabrik Kertas Tjiwi Kimia Tbk. dengan analisis leverage.

\section{Hasil dan Pembahasan}

Leverage merupakan penggunaan aset atau dana, dimana atas penggunaan tersebut perusahaan harus menanggung beban tetap berupa penyusutan atau beban bunga. Ditinjau dari laporan laba rugi, Leverage dibedakan menjadi 3, yaitu leverage operasi, leverage keuangan dan leverage kombinasi.

\subsection{Leverage Operasi}

Leverage operasi merupakan kemampuan EBIT Perusahan untuk merespon fluktuasi penjualan. Semakin besar tingkat penjualan, semakin rendah derajat leverage operasi. Berdasarkan hasil perhitungan dapat dilihat bahwasanya jika penjualan naik maka EBIT juga akan naik dan sebalikya. Hal ini terlihat DOL yang dihasilkan pada tahun 2009 sebesar $-2,9$ ini artinya jika perubahan penjualan sebesar $1 \%$ menyebabkan $-2,9 \%$ perubahan pada EBIT. Pada tahun 2010 DOL yang diperoleh sebesar -2,4 ini artinya jika perubahan penjualan sebasar 1\% akan menyebabkan $-2,4 \%$ perubahan pada EBIT. Kemudian pada tahun 2011 didapat DOL sebasar 11,2 ini artinya jika 1\% perubahan pada penjualan akan menyebabkan 11,2\% perubahan pada EBIT. Dan pada tahun 2012, 2013 dan 2014 terjadi masing-masing DOL yang diperoleh 4,5; 8,5 dan 13,2 ini artinya jika perubahan penjualan sebasar 1\% maka akan menyebabkan masing-masing 4,5\%; 8,5\% dan 13,2\% perubahan pada EBIT. Perubahaan yang terjadi tidak harus $1 \%$ tetapi $10 \%, 25 \%$, dan seterusnya juga bisa tergantung keinginan pembuat laporan keuangan. Perubahan yang terjadi bisa positif dan negatif. DOL yang baik adalah DOL yang mengalami penurunan.

Berikut grafik untuk memperjelas DOL pada tahun 2009 sampai 2014. 


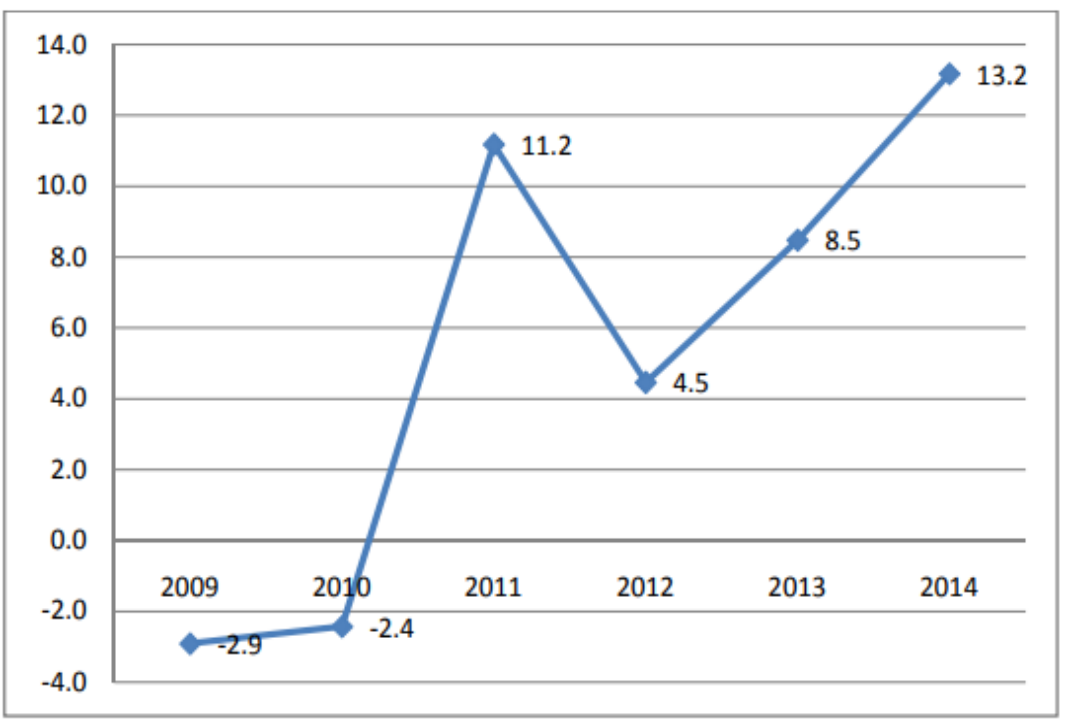

Sumber: data diolah (2020)

Gambar 1. Grafik Perubahan DOL dari tahun 2009 sampai 2014

Dari grafik di atas dapat simpulkan bahwa DOL pada 6 tahun terakhir mengalami kenaikkan ini berarti PT. Pabrik Kertas Tjiwi Kimia Tbk belum mampu mengelola aktiva tetapnya dengan baik sehingga dapat menaikkan risiko bisnis PT. Pabrik Kertas Tjiwi Kimia Tbk tiap tahunnya. Meskipun menggunakan lebih banyak leverage operasi umumnya meningkatkan risiko operasi suatu perusahaan, leverage operasi yang lebih tinggi juga meningkatkan tingkat pengembalian yang diharapkan. Secara detail pada grafik di atas dapat dijelaskan, pada tahun 2009 penjualan mengalami penurunan sebesar -13,59\% tetapi EBIT (laba operasi) mengalami peningkatan sebesar 39,50\%. Hal ini menunjukkan bahwa biaya variabel mengalami penurunan sehingga laba operasi menjadi meningkat. Pada tahun 2010 penjualan mengalami kenaikkan sebesar $14,02 \%$ tetapi EBIT (laba operasi) mengalami penurunan sebesar $-34,06 \%$. Hal ini menunjukkan biaya variabel mengalami peningkatan sehingga EBIT mengalami penurunan. Sedangkan pada tahun 2011 penjualan mengalami kenaikkan sebesar 2,99\% mengakibatkan kenaikkan laba operasi/EBIT sebesar 33,38\%. Hal ini menunjukkan bahwa perusahaan cukup peka terhadap perubahan penjualan. Sementara pada tahun 2012, 2013, dan 2014 penurunan penjualan sebesar $-4,14 \% ;-7,51 \%$ dan $-2,26 \%$ mengakibatkan penurunan laba operasi/EBIT sebesar $-18,49 \%$; $-63,68 \%$ dan $-29,73 \%$. Hal ini menunjukkan bahwa perusahaan cukup peka terhadap perubahan penjualan. Jadi, semakin besar tingkat leverage operasi, samakin peka labaoperasi terhadap perubahaan penjualan dan sebaliknya. Inilah esensi dari analisis operating leverage.

\subsection{Leverage Keuangan}

Leverage keuangan digunakan dengan harapan dapat meningkatkan pengembalian ke pemegang saham biasa. Leverage yang menguntungkan (favorable) atau positif terjadi jika perusahaan dapat menghasilkan pendapatan yang lebih tinggi dengan menggunakan dana yang didapat dalam bentuk biaya tetap tersebut (dana yang didapat dengan menerbitkan utang bersuku bunga tetap atau saham preferen dengan tingkat deviden yang konstan) dari pada dana pembiayaan tetap yang harus dibayar. Berapa pun laba yang tersisa setelah pemenuhan biaya pendanaan tetap, akan menjadi milik para pemegang saham biasa. Leverage yang tidak menguntungkan (unfavorable) atau negatif terjadi ketika perusahaan tidak memiliki hasil 
sebanyak biaya pendanaan tetapnya. Leverage keuangan dapat mengukur besarnya pengaruh perubahan EBIT terhadap EPS.

Berdasarkan hasil perhitungan terlihat bahwa dari 6 tahun terakhir terjadi fluktuasi atau perubahan DFL. DFL yang diperoleh pada tahun 2009 sebesar $-1,0$ ini artinya jika 1\% perubahan pada EBIT akan mengakibatkan -1,0\% perubahan pada EPS. Kemudian pada tahun 2010 didapat DFL sebesar -1,3 ini dapat diartikan jika 1\% perubahan pada EBIT akan mengakibatkan $-1,3 \%$ perubahan pada EPS. Dilanjutkan pada tahun 2011 terdapat DFL sebesar 1,5 dapat diartikan jika 1\% perubahan pada EBIT akan mengakibatkan perubahan 1,5\% pada EPS. Pada tahun 2012 terdapat DFL sebesar 2,8 ini dapat diartikan jika 1\% perubahan pada EBIT akan menimbulkan perubahan 2,8\% pada EPS. Pada tahun 2013 dan 2014 DFL yang diperoleh sebesar 0,4 dan 0,3 dapat diartikan jika 1\% perubahan pada EBIT akan mengakibatkan perubahan $0,4 \%$ dan $0,3 \%$ pada EPS. Perubahaan yang terjadi tidak harus $1 \%$ tetapi $10 \%, 25 \%$, dan seterusnya juga bisa tergantung keinginan pembuat laporan keuangan. Perubahan yang terjadi bisa berpengaruh positif atau negatif. DFL yang baik adalah DFL yang mengalami peningkatan.

Berikut grafik untuk memperjelas DFL pada tahun 2009 sampai 2014

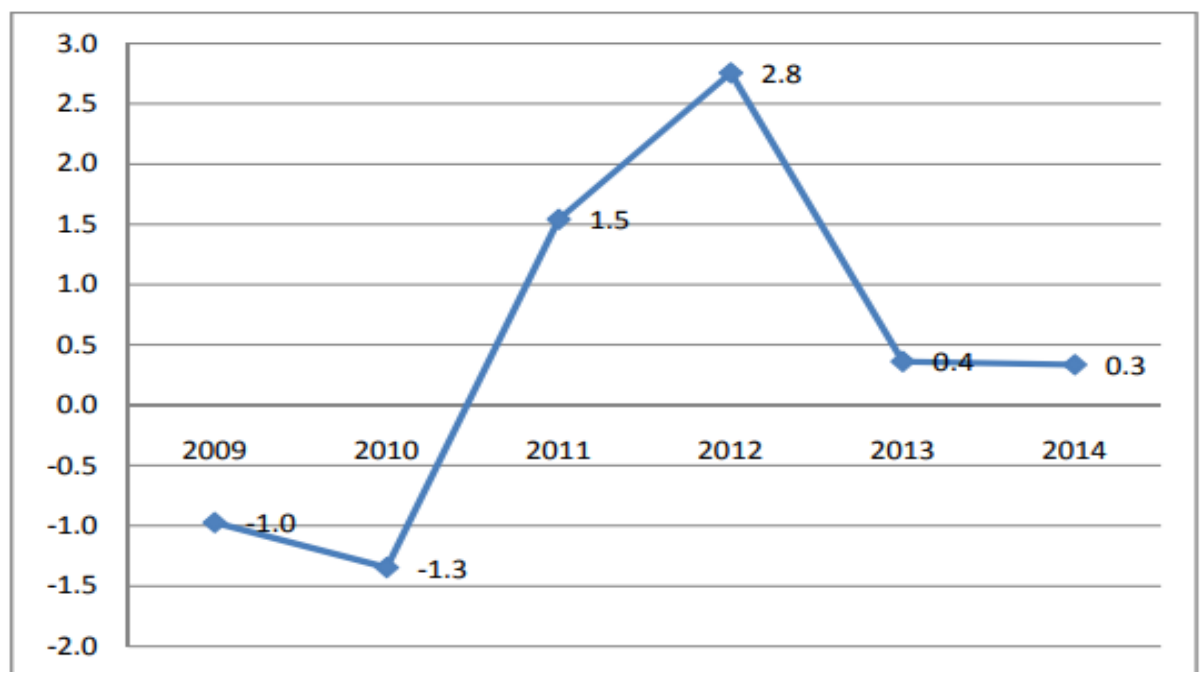

Sumber: data diolah (2015)

Gambar 2. Grafik Perubahan DFL dari tahun 2009 sampai 2014

Dari grafik di atas dapat disimpulkan bahwasanya PT. Pabrik Kertas Tjiwi Kimia Tbk tidak baik dalam penggunaan DFL, hal ini terlihat dari menurunnya DFL tiap tahun sehingga PT. Pabrik Kertas Tjiwi Kimia Tbk mengalami kenaikkan biaya tetap berupa beban bunga. Sehingga PT. Pabrik Kertas Tjiwi Kimia Tbk belum mampu mengurangi risiko keuangannya. Secara detail pada grafik di atas dapat dijelaskan, pada tahun 2009 EBIT mengalami kenaikkan sebesar 39,50\% tetapi EPS mengalami penurunan sebesar -38,46\%. Hal ini menunjukkan ada sesuatu yang aneh yang terjadi pada perusahaan. Pada tahun 2010 EBIT mengalami penurunan sebesar $-34,06 \%$ dan EPS mengalami kenaikkan 45,83\%. Hal ini hampir sama dengan tahun 2009 tetapi yang terjadi sebaliknya. Perusahaan perlu memperhatikan keadaan perusahaan yang mengalami perbedaan ini. Sedangkan pada tahun 2011 EBIT mengalami kenaikkan 33,38\% dan EPS juga mengalami kenaikkan 51,43\%. Hal ini menunjukkan kondisi perusahaan pada tahun tersebut cukup baik. Sementara pada tahun 2012, 2013, dan 2014 DFL mengalami penurunan tiap tahun sebesar -18,49\%; - 63,68\% dan - 
$29,73 \%$ dan EPS juga mengalami penurunan -50,94\%; - 23,08\% dan -10,00\%. Hal ini menunjukkan semakin besar dampak perubahan laba operasi (EBIT) pada laba setelah pajak dan hal ini terjadi pada saat perusahaan membayar bunga yang makin besar (yang berarti hutangnya juga semakin besar). Dengan kata lain, semakin besar hutang yang digunakan oleh perusahaan, semakin tinggi tingkat financial leveragenya. Tujuan dari DFL adalah meningkatkan tingkat pengembalian kepada pemegang saham dalam meningkatkan EPS.

\subsection{Leverage Total}

Leverage kombinasi merupakan perkalian antara leverage operasi dan leverage keuangan guna untuk melihat leverage secara total. Tidak selamanya keduanya berbanding lurus, artinya tidak selamanya DOL yang naik akan diikuti dengan DFL yang naik pula. Jika DOL memiliki tingkat leverage yang tinggi tetapi DFL menunjukan penurunan tetapi jika dikalikan akan menghasilkan leverage yang negatif. Informasi DTL menjadi penting agar mendapatkan gambaran secara total antara efisiensi dan efektifitas operasi perusahaan yang di kombinasikan dengan strategipendanaan perusahaan.

Berdasarkan hasil perhitungan, terlihat pada 6 tahun terakhir terjadi penurun dan penaikkan (tidak stabil) DTL pada perusahaan. Terlihat pada tahun 2009 DTL yang diperoleh sebasar 2,8 ini dapat diartikan jika $1 \%$ perubahan pada penjualan akan mengakibatkan $2,8 \%$ perubahan pada EPS. Pada tahun 2010 DTL yang diperoleh sebesar 3,3 ini dapat diartikan jika 1\% perubahan pada penjualan akan mengakibatkan 3,3\% perubahan pada EPS. Kemudian pada tahun 2011 DTL yang diperoleh 17,2 ini artinya jika 1\% perubahan pada penjualan akan mengakibatkan 17,2\% perubahan pada EPS. Pada tahun 2012, 2013 dan 2014 DTL yang di peroleh masing-masing 12,$3 ; 3,1$ dan 4,4 ini artinya jika perubahan penjualan sebesar $1 \%$ akan mengakibatkan perubahan EPS masing-masing 12,3\%; 3,1\% dan 4,4\%. Perubahan yang terjadi bisa mengarah pada peningkatan bahkan penurunan. DTL yang baik adalah DTL yang mengalami penurunan.

Berikut grafik untuk memperjelas DTL pada tahun 2009 sampai 2014.

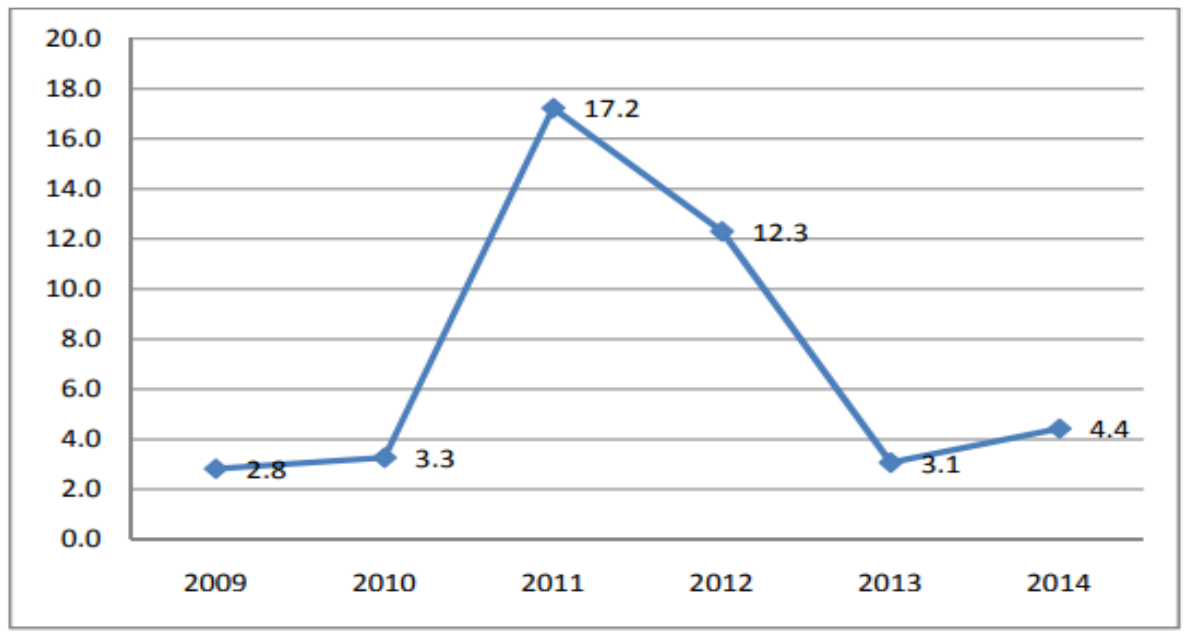

Sumber : data diolah (2015)

Gambar 3. Grafik Perubahan DTL dari tahun 2009 sampai 2014

Dari perhitungan di atas dapat di simpulkan DTL yang dihasilkan PT. Pabrik Kertas Tjiwi Kimia Tbk tidak konsisten tiap tahunnya sehingga dapat disimpulkan bahwa PT. Pabrik Kertas Tjiwi Kimia Tbk masih mampu memperkecil risiko bisnis dan risiko keuangannya jika 
bisa menurunkan DOL dan meningkatkan DFL. Secara detail pada grafik di atas dapat dijelaskan, pada tahun 2009 terjadi penurunan penjualan sebesar -13,59\% dan EPS turun sebesar - 38,46\%. Angka ini menunjukkan kombinasi leverage operasi dan leverage financial. Hal yang sama juga terjadi pada tahun 2012, 2013, dan 2014 sama dengan tahun 2009 mengalami penurunan penjualan sebesar $-4,14 \%$; - 7,51\% dan $-2,26 \%$ dan EPS penurunan sebesar $-50.94 \%$; $-23,08 \%$ dan - 10,00\%. Hal ini menunjukkan kombinasi antara dua leverage. Tetapi pada tahun 2010 dan 2011 terjadi kenaikkan penjualan sebesar 14,05\%; dan $2,99 \%$ dan EPS juga mengalami kenaikkan sebesar 45,83\% dan 51,43\%. Semakin besar angka ini berarti semakin besar pengaruh perubahaan penjualan terhadap perubahaan laba setelah pajak. Hal ini akan terjadi apabila DOL sudah tinggi diikuti dengan DFL yang tinggi. Karena itu, umumnya perusahaan akan menghindari financial leverage yang tinggi apabila operating leveragenya (yang mencerminkan risiko bisnis) sudah tinggi.

\section{Kesimpulan}

Setelah mempelajari dan menganalisis data dan laporan keuangan PT. Pabrik Kertas Tjiwi Kimia Tbk, selama enam periode dengan menggunakan analisis leverage maka peneliti dapat mengambil kesimpulan sebagai berikut: (1) Tingkat risiko operasi pada PT. Pabrik Kertas Tjiwi Kimia Tbk berdasarkan DOL (Degree of Operation leverage) dengan menggunakan analisis Leverage operasi, 6 tahun terakhir belum baik, karena enam tahun terakhir mengalami kecendrungan kenaikkan ini berarti PT. Pabrik Kertas Tjiwi Kimia Tbk belum mampu mengurangi risiko bisnisnya. (2) Tingkat risiko keuangan pada PT. Pabrik Kertas Tjiwi Kimia Tbk berdasarkan DFL (Degree of financial leverage) dengan menggunakan analisis Leverage keuangan, tidak baik, karena terjadinya penurunan pada EPS yang dihasilkan. Kecendrungan penurunan DFL yang dihasilkan memperlihatkan PT. Pabrik Kertas Tjiwi Kimia Tbk belum mampu mengurangi risiko keuangannya. (3) Tingkat risiko total pada PT. Pabrik Kertas Tjiwi Kimia Tbk berdasarkan DCL (Degree of combined leverage) dengan menggunakan analisis Leverage operasi keuangan, tiap tahun cenderung mengalami kenaikan dan penurunan (tidak konsisten) terlihat dari variasi EPS yang dihasilkan tiap tahunnya yang diikuti naik turun penjualan. PT. Pabrik Kertas TjiwiKimia Tbk mampu memperkecil total risikonya jika bisa menurunkan DOL dan meningkatkan DFL. Dari perhitungan tersebut selama 6 tahun terakhir dapat disimpulkan kesehatan PT. Pabrik Kertas Tjiwi Kimia Tbk diukur dari Analisis Leverage 6 tahun terakhir masih perlu perhatian serius karena PT. Pabrik Kertas Tjiwi Kimia Tbk belum mampu memperkecil risiko operasi, risiko keuangan dan risiko totalnya.

Berdasarkan hal-hal yang dikemukakan dalam kesimpulan, maka untuk perbaikan perusahaan kedepannya peneliti menyarankan agar: (1) DOL pada PT. Pabrik Kertas Tjiwi Kimia Tbk kurang, PT. Pabrik Kertas Tjiwi Kimia Tbk harus berusaha meningkatkan penjualan yang mengakibatkan EBIT meningkat untuk menghasilkan DOL yang lebih rendah. (2) DFL pada PT. Pabrik Kertas Tjiwi Kimia Tbk kurang, PT. Pabrik Kertas Tjiwi Kimia Tbk harus berusaha meningkatkan DFL yang stabil dan cendrung mengalami penurunan harus di tingkatkan guna mendapatkan EPS yang lebih tinggi dan mengurangi risiko keuangannya. (3) DTL pada PT. Pabrik Kertas Tjiwi Kimia Tbk masih tidak konsisten, PT. Pabrik Kertas Tjiwi Kimia Tbk agar berusaha meningkatkan penjualan yang berdampak pada EBIT yang di peroleh guna mengurangi resiko operasi dan risiko keuangan.

Data yang digunakan dalam penelitian ini adalah data sekunder, sehingga peneliti tidak bisa mengendalikan dan mengawasi kemungkinan terjadinya kesalahan dalam perhitungan. Selain itu, objek penelitian hanya berfokus kepada satu perusahaan saja, diharapkan untuk penelitian 
selanjutnya mengambil perusahaan dalam jumlah besar. Variabel yang digunakan hanya berfokus kepada satu rasio saja, sementara banyak rasio-rasio keuangan lainnya yang dapat menjadi patokan dalam mengukur kinerja perusahaan.

\section{Referensi}

Brigham \& Houston. (2001). Manajemen Keuangan Buku 2. Edisi 8. (diterjemahkan oleh: Dodo Suharto, Herman Wibowo). Jakarta: Erlangga.2001.

Brigham \& Houston. (2007). Dasar-dasar Manajemen Keuangan Essentials of Financial Management Buku 2. Edisi 11. (diterjemahkan oleh: Ali Akbar Yulianto). Jakarta: Salemba Empat. 2011.

Brigham \& Houston. 2007. Dasar-dasar Manajemen Keuangan Essentials of Financial Management Buku 1. Edisi 11. (diterjemahkan oleh: Ali Akbar Yulianto). Jakarta: Salemba Empat.2010.

Charette, Robert. (2006). Manajemen Resiko dalam Pengembangan Perangkat Lunak. Prentice Hall.

Darmawi, Hermawan. (2010). Manajemen Risiko. Jakarta: Bumi Aksara.

Dina, Novia. (2007). Modul Manajemen Keuangan. Malang: Universitas Brawijaya.

Fahmi, Irham. (2011). Manajemen Risiko Teori, Kasus, dan Solusi. Bandung: Alfabeta.

Halim, Abdul. (2007). Manajemen Keuangan Bisnis. Bogor: Ghalia Indonesia.

Halim, dkk. (2005). Pengaruh Manajemen Laba pada Tingkat Pengukuran Laporan Keuangan Manufaktur Termasuk dalam Indeks LQ-45. SNA Solo. 8.1.

Horne, James C. Van. \& Wachowich, John M. (2007). Financial Management; Prinsipprinsip Manajemen Keuangan.Edisi 12. Jakarta: Salemba Empat.

Husnan, Suad. (2008). Manajemen Keuangan, Teori dan Penerapan (Keputusan Jangka Panjang) Buku 1 Edisi 4. Yogyakarta: BPFE.

Idroes, Ferry N. (2011). Manajemen Risiko Perbankan. Jakarta: Rajawali Pers.

Jumingan. (2009). Analisis Laporan Keuangan. Jakarta: PT. Bumi Askara.

Keown, Arthur J. (2005). Prinsip dan PenerapanManajemen Keuangan Jilid 2.Edisi 10. (diterjemahkan oleh: Marcus Prihminto Widodo). Jakarta: PT. Indeks.2010.

PT. Pabrik Kertas Tjiwi Kimia Tbk. 2008-2014. Counting Stars : App Products that Shape the World Today Annual Report. Diunduh tanggal 12 Januari 2015, Http://idx.co.id.

Setiawan, Ebta. (2013). KBBI Offline Versi 1.5.1 Diunduh tanggal 10 Januari 2015, Http://pusatbahasa.kemdiknas.go.id/kbbi/

Subramanyam dan Wild. (2011). Analisis Laporan Keuangan Buku 1 Edisi 10.Jakarta : Salemba Empat.

Sugiyono. (2010). Metode Penelitian Bisnis. Bandung: Alfabeta.

Surat Edaran Ketua Badan Pengawas Pasar Modal. (2002). Pedoman Penyajian dan Pengungkapan Laporan Keuangan Emiten atau Perusahaan Publik Industri Manufaktur. Jakarta: BAPEPAM. 
Syamsuddin, Lukman. (2009). Manajemen Keuangan Perusahaan. Jakarta: PT. Raja Grafindo Persada.

Tandelilin, Eduardus. (2001). Analisis dan Manajemen Portofolio Edisi Pertama. Yogyakarta: BPFE.

Tariqullah, Khan \& Habib, ahmed. (2008). Manajemen Risiko ; Lembaga Keuangan Syariah. Jakarta : PT. Bumi Askara.

Unit FE. (2012). Panduan Penulisan Tugas Akhir Program Diploma III FE UNP. Fakultas Ekonomi: Universitas Negeri Padang.

Yulianti, Retno \& Zuhrohtun. (2006). Operating Leverage dan Risiko Sistematik Perusahaan. Jurnal Ekonomi dan Kewirausahaan, Vol. 6, No. 1, April 2006: 1-6.

\section{Copyrights}

Copyright for this article is retained by the author(s), with first publication rights granted to the journal.

This is an open-access article distributed under the terms and conditions of the Creative Commons Attribution license (http://creativecommons.org/licenses/by/4.0/) 